\title{
A new species and new records of dance flies of the subgenus Empis s.str. (Diptera: Empididae) from European Russia
}

\author{
Новый виА и новые указания мух-толкунчиков подрода \\ Empis s.str. (Diptera: Empididae) из Европейской части России
}

\author{
I.V. Shamshev ${ }^{1}$, O.N. Berezhnova ${ }^{2,3}$ \\ И.В. Шамшев ${ }^{1}$, О.Н. Бережкнова ${ }^{2,3}$
}

\footnotetext{
${ }^{1}$ Zoological Institute, Russian Academy of Sciences, Universitetskaya nab. 1, St. Petersburg 199034, Russia. Corresponding author, E-mail: shamshev@mail.ru

1 Зоологический институт РАН, Университетская наб. 1, С.-Петербург 199034, Россия.

2 Voronezh State University, Universitetskaya pl. 1, Voronezh 394036, Russia. E-mail: berezhnova@bio.vsu.ru

2 Воронежский государственный университет, Университетская пл. 1, Воронеж 394036, Россия.

3 "Galichya Gora” Nature Reserve, Donskoe, Lipetskaya Province 399240, Russia.

3 Заповедник “Галичья Гора", Донское, Липецкая обл. 399240, Россия.
}

KEYWORDS. Diptera, Empididae, Empis, new species.

КЛЮЧЕВЫЕ СЛОВА. Diptera, Empididae, Empis, новый вид.

ABSTRACT. New data on dance flies of the subgenus Empis s.str. (Diptera: Empididae) from the central part of European Russia are provided. A new species, Empis (Empis) mediorossica sp.n., is described from Lipetskaya Province ("Galichya Gora"Nature Reserve). Eight species of Empis s. str. are recorded for the first time from Centralno-Chernozemny Nature Reserve (Kurskaya Province). Empis (Empis) bohemica Chvála et Syrovátka, 1989 and E. (E.) planetica Collin, 1927 are found for the first time from the territory of Russia (Kurskaya and Moskovskaya Provinces, respectively).

РЕЗЮМЕ. Представлены новые сведения по мухам-толкунчикам подрода Empis s.str. (Diptera: Empididae) центральных регионов Европейской части России. Описан новый вид, Empis (Empis) mediorossica sp.n., из Липецкой области (заповедник «Галичья Гора»). Восемь видов впервые указываются из Центрально-Чернозёмного заповедника (Курская область). Empis (Empis) bohemica Chvála et Syrovátka, 1989 и E. (E.) planetica Collin, 1927 впервые найдены на территории России (Курская и Московская области, соответственно).

\section{Introduction}

The Palaearctic fauna of the Empis Linnaeus, 1758 nominative subgenus includes currently about 170 species. These flies, being active flower-visitors, are usually a marked element of spring and early summer biota.
The group is more diverse in submontane regions but it is also quite well represented in low-land areas. Empis s. str. is still poorly known from the territory of Russia, with 48 recorded species, about a half of which were described from the Caucasus [Shamshev, 2016]. In our paper we provide new data on Empis s. str. from steppe and forest-steppe regions of central part of the European Russia. A new species is described from "Galichya Gora" Nature Reserve (Lipetskaya Province). Also, we include for the first time a list of eight species of Empis s. str. occurring in Centralno-Chernozemny Nature Reserve (Kurskaya Province) and present new records of this group from some other provinces.

\section{Materials and Methods}

This study is based on the Empididae material deposited in the Zoological Museum of Moscow State University, Moscow, Russia (ZMUM), the Zoological Institute, Russian Academy of Sciences, St. Petersburg, Russia (ZIN) and the Department of invertebrate ecology and systematics of Voronezh State University, Voronezh, Russia (VSU). Specimens from ZMUM were collected by A.L Ozerov, K.P. Tomkovich and N.E. Vikhrev in Centralno-Chernozemny Nature Reserve (Kurskaya Prov.) as well as by D.I. Gavryushin in environs of Moscow. O.N. Berezhnova (= Chalaya) collected materials from Belgorodskaya, Lipetskaya ("Galichya Gora" Nature Reserve) and Tambovskaya Provinces. Shamshev [2016] already noted these records in the Checklist

How to cite this article: Shamshev I.V., Berezhnova O.N. 2019. A new species and new records of dance flies of the subgenus Empis s.str. (Diptera: Empididae) from European Russia // Russian Entomol. J. Vol.28. No.1. P.86-90. doi: 10.15298/rusentj.28.1.15 
of empidoid flies of Russia but without documentary data. Dry, pinned specimens were used. Describing new species, to facilitate observations, the terminalia were macerated in cold $10 \% \mathrm{KOH}$, then put for a short period in $85 \%$ lactic acid and immersed in glycerine. The terms used for adult structures primarily follow those summarized by Cumming and Wood [2009]. The pictures of the male and female habitus were produced using a Nikon SMZ 1500 stereomicroscope equipped with a Nikon D700 digital SLR camera and were aligned and stacked using the Helicon Focus 5.3.14 software. The label data for the holotype are cited from top downward, with the data from each label in quotation marks. Labels are cited in full, with original spelling, punctuation, and date, and label lines are delimited by a slash (/). Additional information is included in square [ ] brackets. Secondary type data are abridged. Global distribution data for species noted in our paper were taken from Shamshev [2016]. Species are arranged in alphabetic order. The following abbreviations are used: Prov. — Province (= oblast), NR — Nature Reserve.

\section{Taxonomic account}

Class Insecta Linnaeus, 1758

Order Diptera Linnaeus, 1758

Suborder Brachycera Macquart, 1834

Superfamily Empidoidea Latreille, 1804

Family Empididae Latreille, 1804

Genus Empis Linnaeus, 1758

Empis (Empis) acinerea Chvála, 1985

MATERIAL. Russia: Kurskaya Prov.: $4 \sigma^{\top} \sigma^{\top}$, Centralno-Chernozemny NR, Streletskaya Steppe, 5-10.V.2008, K. Tomkovich (ZMUM).

NOTE. This species is mostly known from temperate Europe but also it was found in Turkey and recorded from several localities in the European part of Russia including Karelia, Leningradskaya, Pskovskaya, Kurskaya, Voronezhskaya provinces and Krasnodarskiy Territory.

DISTRIBUTION. Belgium, Czech Republic, Denmark, Finland, Germany, Russia, Slovakia, Sweden, Switzerland, the Netherlands, Turkey.

Empis (Empis) albopilosa de Meijere, 1935

MATERIAL. Russia: Kurskaya Prov.: $1 \sigma^{\top}$, Centralno-Chernozemny NR, Bukreevy Barmy, 6.V.2008, K. Tomkovich (ZMUM)

NOTE. The species has been known from western, central Europe and two localities in the European part of Russia (Voronezhskaya Prov., Krasnodarskiy Territory).

DISTRIBUTION. Belgium, Czech Republic, Germany, Switzerland, the Netherlands, Russia.

\section{Empis (Empis) anfractuosa Mik, 1884}

MATERIAL. Russia: Belgorodskaya Prov.: $1 \sigma^{7}, 1$ q, $11 \mathrm{~km}$ WNW of Valuyki, shore of Oskol River, 20.V.1991, O.N. Chalaya (VSU). Kurskaya Prov.: $10 \sigma^{\top} \sigma^{\top}, 2$ of, Centralno-Chernozemny Nature Reserve, Streletskaya Steppe, 5-10.05.2008, K. Tomkovich (ZMUM). Lipetskaya Prov.: 10 males, 5 females, $25 \mathrm{~km}$ N of Zadonsk, "Galichya gora" NR, 10-11.V.2002, O.N. Berezhnova (VSU).

NOTE. The species has been known from Central Europe and Voronezhskaya Province of Russia.

DISTRIBUTION. Austria, Czech Republic, Germany, Hungary, Slovakia, Switzerland, Russia.
Empis (Empis) bohemica Chvála et Syrovátka, 1989

MATERIAL. Kurskaya Prov.: 2 ' $\sigma^{7}$ Centralno-Chernozemny NR, Bukreevy Barmy, 6.V.2008, K. Tomkovich (ZMUM).

NOTE. The species is known only from Central Europe. It is recorded for the first time from the territory of Russia.

DISTRIBUTION. Austria, Czech Republic, Hungary, Slovakia, Russia.

Empis (Empis) caudatula Loew, 1867

MATERIAL. Russia: Kurskaya Prov.: 1 フ , Centralno-Chernozemny NR (Selikhovy Dvory, $\left.51.5751671^{\circ} \mathrm{N}, 36.089359^{\circ} \mathrm{E}\right), 20$ 21.VII.2007, A.L. Ozerov (ZMUM). Lipetskaya Prov.: 1 ○’, 3 우, environs of Chaplygin, 3.VI.1992, O.N. Chalaya (VSU). Tambovskaya Prov.: 1 万', $32 \mathrm{~km}$ N of Morshansk, shore of Tsna River, 16.VI.1991, O.N. Chalaya (VSU).

NOTE. This species is quite common in lowlands of temperate part of Europe and, additionally, is known from Turkey. Also, it has been recorded from Samarskaya and Voronezhskaya provinces of Russia.

DISTRIBUTION. Austria, Belgium, Czech Republic, Denmark, France, Germany, Great Britain, Hungary, Lithuania, Norway, Poland, Slovakia, Slovenia, Sweden, Switzerland, Russia, the Netherlands, Turkey.

Empis (Empis) dasyprocta Loew, 1867

MATERIAL. Russia: Kurskaya Prov:: $1 \sigma^{7}$, Centralno-Chernozemny NR (Streletskaya steppe, $51.565161^{\circ} \mathrm{N}, 36.084226^{\circ} \mathrm{E}$ ), 20-21.VII.2007, A.L. Ozerov (ZMUM).

NOTE. The species is known from western and central parts of Europe. Also, it is quite widely distributed in the European part of Russia (previous records from Belgorodskaya, Pskovskaya, Samarskaya, Smolenskaya and Voronezhskaya provinces).

DISTRIBUTION. Czech Republic, Germany, Italy, Slovakia, Spain, the Netherlands, Russia.

Empis (Empis) impennis Strobl, 1902

MATERIAL. Russia: Kurskaya Prov.: $2 \sigma^{\top} \sigma^{7}$, Centralno-Chernozemny NR (Streletskaya steppe, $51.5751671^{\circ} \mathrm{N}, 36.089359^{\circ} \mathrm{E}$ ), 20.VII.2007, N. Vikhrev (ZMUM); 1 万', same locality, 2021.VII.2007, A.L. Ozerov (ZMUM). Lipetskaya Prov.: $5 \sigma^{7} \sigma^{7}, 25$ km N of Zadonsk, "Galichya gora" NR, 4.VII.1990, O.N. Chalaya (VSU).

NOTE. This species is quite widely distributed in Europe. Also, it has been known from several localities in the European part of Russia (Kaluzhskaya, Voronezhskaya, Belgorodskaya, Samarskaya Provinces).

DISTRIBUTION. Austria, Croatia, Czech Republic, France, Germany, Great Britain, Hungary, Poland, Romania, Russia, Slovakia, Slovenia, Switzerland, the Netherlands.

\section{Empis (Empis) mediorossica \\ Shamshev et Berezhnova, sp.n. Figs 1-4.}

TYPE MATERIAL. Holotype - $\mathrm{O}^{2}$, labelled [printed in Cyrillic, Russian]: RUSSIA: " $25 \mathrm{~km} \mathrm{~N}$ of Zadonsk/ Galichya gora $\left[52^{\circ} 36^{\prime} \mathrm{N}, 38^{\circ} 55^{\prime} \mathrm{E}\right] /$ Lipetskaya Prov./ Berezhnova 11.V.02"; "swarming near top of trees"; "Empis (Empis) mediorossica Shamshev et Berezhnova, sp. n.” (ZIN, INS_DIP_0000694).

Paratypes. RUSSIA: Lipetskaya Prov.: $100^{7} 0^{7}$, same data as holotype (ZIN). $1 \sigma^{\top}, 25 \mathrm{~km} \mathrm{~N}$ of Zadonsk, Morozova gora, edge of oak wood, 1.VI.02, Berezhnova (VSU). $1 \sigma^{7}, 1$,, $25 \mathrm{~km} \mathrm{~N}$ of Zadonsk, near Galichya gora, right bank of Don River, spring brook near swamp, 11.V.2002, Berezhnova (VSU).

DIAGNOSIS. Mid-sized species with body lengths about $4 \mathrm{~mm}$; legs almost entirely yellow, only apical tarsomeres darkened; labrum moderately long, about 2 times of head height; thorax with black setation; halter yellow; abdomen 


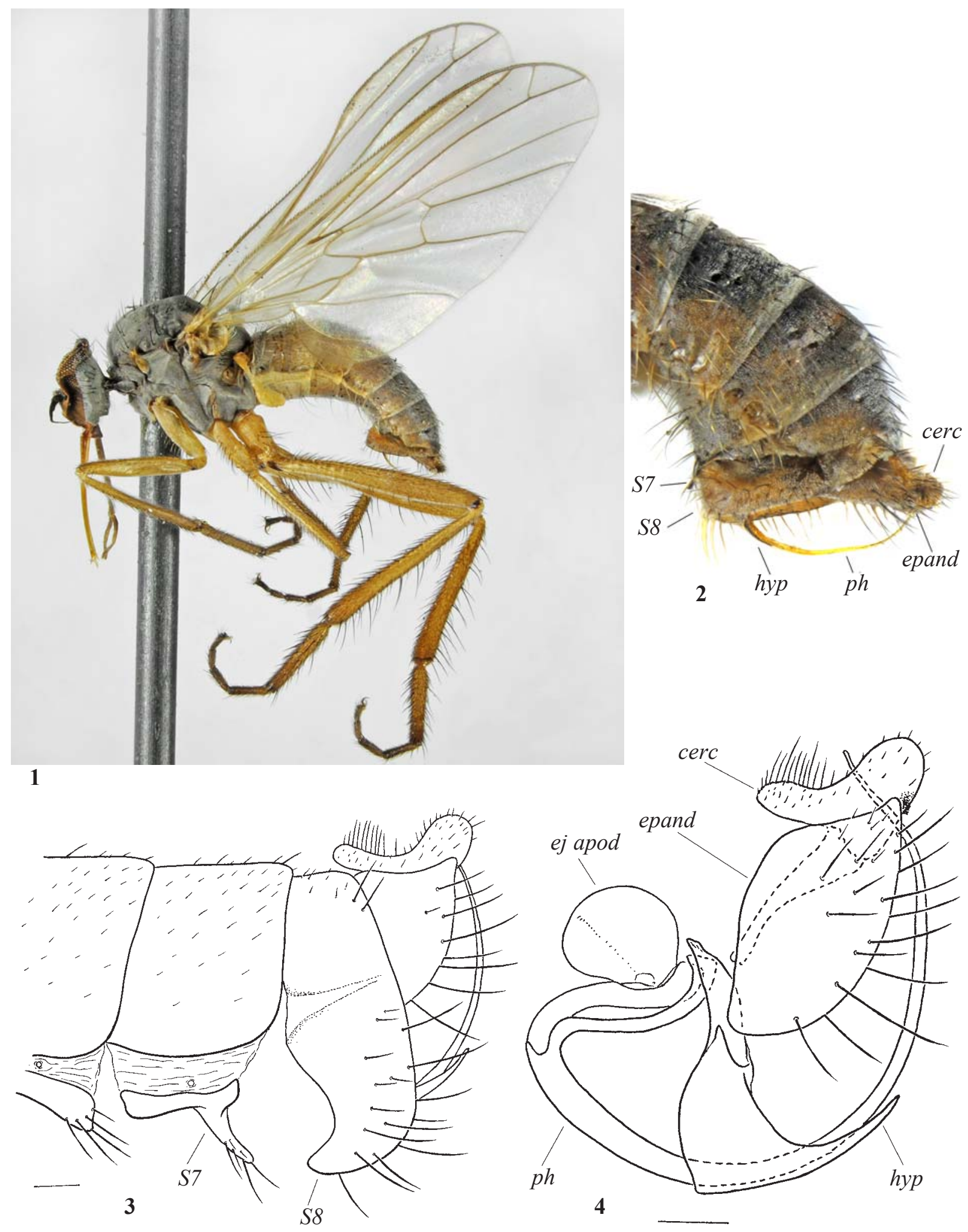

Figs 1-4. Empis (Empis) mediorossica sp.n., male: 1 - habitus, lateral view, holotype; 2, 3 - postabdomen, lateral view; 4 - terminalia, lateral view. Abbreviations: cerc — cercus; ej apod — ejaculatory apodeme; epand — epandrium; hypd — hypandrium; ph — phallus; S7 — sternite 7; S8 - sternite 8. Scale bar: $0.1 \mathrm{~mm}$.

Рис. 1-4. Empis (Empis) mediorossica sp.n., самец: 1 - габитус, сбоку, голотип; 2, 3 - постабдомен, сбоку; 4 - терминалии, сбоку. Сокращения: cerc - церк; еј ароd — эякуляторная аподема; epand — эпандрий; hyрd — гипандрий; ph — фаллус; S7 — 7й стернит; S8 - 8-й стернит. Масштаб: 0,1 мм. 
mostly yellowish; wing with anal vein complete. Male: legs with simple tarsomeres, mid tibia with $2-3$ long dorsal setae, abdominal sternite 7 with digitiform projection postero-medially; phallus slender, evenly bowed. Female: mid, hind femora and hind tibia pinnate.

DESCRIPTION. Body length: 4.0-4.3 (holotype 4.1) $\mathrm{mm}$; wing length: 5.0-5.2 (holotype 5.1) mm. Male (Fig. 1). Head black, mostly with black setation. Eyes holoptic; upper ommatidia enlarged. Frons reduced to small greyish triangular space above antennae, bare. Face broad, bare, densely greyish pollinose. Ocellar tubercle with 2 moderately long hair-like and 2 minute setae. Occiput densely greyish pollinose; with rather sparse setae of different lengths on upper part and pale hair-like setae on lower part behind mouthopening. Antenna black; scape and pedicel with short setulae; postpedicel conical, about 2.5 times longer than wide; stylus slightly shorter than postpedicel. Labrum brownish yellow; 1.6-1.8 times as long as head is high. Palpus black, with scattered black setulae.

Thorax black, densely greyish pollinose, with black setation. Scutum viewed dorsally with hardly prominent darker vittae between rows of acrostichal and dorsocentral setae, uniformly greyish viewed anteriorly. First cervical sclerite bare. Prosternum bare. Proepisternum with 4-6 short setae on lower portion (sometimes yellow setae present) and bare on upper portion. Antepronotum convex, with several short setae. Postpronotal lobe with 1 long and several short setae. Mesonotum with 1 long presutural supra-alar (sometimes with additional setulae), 3 notopleurals with several additional brownish yellow to yellow setulae anteriorly, 2-3 postsutural supra-alars of different lengths (posterior seta longest), 1 postalar and 4 scutellars (apical pair distinctly longer and stronger); acrostichals arranged in 2 irregular rows, short, somewhat lateroclinate, ending before prescutellar depression; dorsocentrals mostly arranged in 2 irregular rows, short and somewhat lateroclinate, becoming uniserial on prescutellar depression (also sometimes on anterior part of scutum), 2 prescutellar pairs long (nearly as long as apical pair of scutellars). Laterotergite with several setae of different lengths (sometimes brownish yellow setae present). Anterior and posterior spiracles yellow.

Legs, including coxae, almost uniformly yellow, only apical tarsomeres darkened; with black setation. Coxae and trochanters with simple setae of different lengths. Fore femur covered with simple setulae. Fore tibia pubescent with fine setulae ventrally, lacking prominent setae (except circlet of short subapicals). Fore tarsomeres slender, pubescent with fine setulae ventrally, bearing circlet of short subapical setae. Mid femur whitish pubescent ventrally, with row of anteroventral setae, which are very short on apical $1 \backslash 3$ and long on basal 2/3 (longer than femur is wide), row of similar but shorter posteroventral setae and some prominent anterodorsal setae longer toward base of femur. Mid tibia usually with 2-3 dorsal setae on about basal 2/3 (anterior seta always nearly 2 times as long as tibia is wide, remaining setae varying in length and sometimes absent), rows of anteroventral and posteroventral setae of different lengths and circlet of mostly short subapical setae ( 1 anterodorsal seta very long). Mid tarsomeres slender, tarsomeres 1-4 bearing circlet of mostly short subapical setae, tarsomere 1 with ventral spinulelike setulae and 1 long anterodorsal subapical seta. Hind femur slightly narrowed on basal part, with row of thin anteroventral setae of different lengths (several longest setae somewhat shorter than femur is wide), numerous erect spinulelike setulae on apical part posteriorly and some moderately long yellowish brown setae closer to base posteriorly. Hind tibia somewhat narrowed near base, otherwise slightly thickened and nearly as wide as hind femur on apical portion; bearing numerous long (longer than tibia is wide) anterodorsal and posterodorsal setae, covered with short anteroventral and posteroventral setae. Hind tarsomere 1 slightly thickened on basal part but narrower than hind tibia at tip, with some longer setae dorsally and spine-like setae ventrally.

Wing membrane hyaline. Costal seta present, short. Pterostigma indistinct. Veins largely brownish, paler closer to base, well sclerotised. Radial fork rather broad. Anal vein complete. Cell dm short, truncate. Anal angle acute, anal lobe well developed. Calypter yellow, with concolorous fringe. Halter yellow.

Abdomen mostly dirty yellow to yellow, densely greyish pollinose; segment 1 entirely, segments 2 and 5-7 anteriorly, sternites 5-7 entirely more or less darkened. Tergites with moderately long yellowish setae laterally, covered with black short setae dorsally. Segments 7-8 modified (Figs 2-3); tergite 7 slightly convex posteriorly, sternite 7 with long, digitiform projection postero-medially; sclerites of segment 8 fused (traces of pleural area distinct), tergite 8 very narrow, flattened dorsally, in situ partly hidden by tergite 7 , sternite 8 concave on about middle anterolaterally, with anteroventral margin somewhat projected, subtriangular in ventral view. Terminalia (Fig. 4) small; cerci and epandrium yellowish brown, with short black unmodified setae, hypandrium tomentose basally and shining apically. Cerci narrowly fused anteriorly, mostly covered with moderately long setae; cercus broadly concave dorsally (lateral view), rounded posteriorly, with small internal lobe covered black spinules. Epandrial lamella subtriangular (lateral view), with rather scattered long setae along lower margin and closer to apex. Hypandrium bare, subtriangular (ventral view). Phallus yellow, thin, long, evenly arcuate.

Female. Eyes dichoptic, with ommatidia equally small. Frons broad, densely greyish pollinose, with minute marginal setulae, almost parallel-sided. Fore tibia and tarsus with ordinary setulae ventrally. Mid femur pinnate anterodorsally (except extreme apex and base) and posteroventrally (except extreme base); mid tibia with some flattened ventral setae closer to base. Hind femur with longer flattened setae; pinnate dorsally (except extreme apex) and ventrally (except extreme base); hind tibia pinnate on basal half ventrally and along dorsal face. Wing membrane slightly brownish infuscate. Abdomen largely dusky yellow, segments 6-8 dark, entirely greyish pollinose; covered mostly with short black setae, with some yellowish setae near base laterally. Cercus brown, elongate, covered with dark minute setulae. Otherwise as in male.

ETYMOLOGY. The name of the new species refers to the whole region of its origin.

DIFFERENTIAL DIAGNOSIS. The new species in the structure of the male postabdomen is similar to E. malleola Becker, 1887 known from Alps [Syrovátka, 1991]. However, E. mediorossica sp.n. is somewhat smaller (body lengths 4$4.3 \mathrm{~mm}$ versus $5.3-5.6 \mathrm{~mm}$ in E. malleola), it has almost entirely yellow legs (vs. dark brown), clear wings (vs. brownish), black setae on laterotergite (vs. whitish yellow) and different structure of the male postabdomen. Prov.)

DISTRIBUTION. PALAEARCTIC: Russia (Lipetskaya

HABITAT AND SEASONAL OCCURRENCE. According to observations of O.N. Berezhnova E. mediorossica sp.n. probably is an early spring species (like many other members of Empis s.str.), flying for a short period at the beginning of May. Most part of the males of the type series was collected from a swarm near top of trees. 
Empis (Empis) nitidissima Strobl, 1893

MATERIAL. Russia: Kurskaya Prov.: $6 \sigma^{7} \sigma^{7}$, Centralno-Chernozemny NR, Bukreevy Barmy, 6.V.2008, K. Tomkovich (ZMUM); $1 \Im^{7}$, Streletskaya Steppe, 5-10.V.2008, K. Tomkovich (ZMUM).

NOTE. The species is known from central and southern Europe and after a single record from Voronezhskaya Prov. of Russia [Berezhnova, Shamshev, 2006].

DISTRIBUTION. Austria, Bosnia and Herzegovina, Czech Republic, Germany, Hungary, Slovakia, Russia.

Empis (Empis) planetica Collin, 1927

MATERIAL. Russia: Moskovskaya Prov.: $2 \sigma^{\top} \sigma^{7}$, Naro-Fominsk, 55.364326N 36.741089E, 03.VI.2008, D. Gavryushin (ZMUM).

NOTES. The species is quite widely distributed in Europe but it is recorded for the first time from the territory of Russia.

DISTRIBUTION. Belgium, Czechia, Denmark, Germany, Great Britain, Ireland, Italy, Norway, Romania, Slovakia, Sweden, Switzerland, the Netherlands, Russia.

Acknowledgments. We are indebted to A.L. Ozerov (ZMUM) for the loan of specimens used in this study. F.V. Konstantinov (Department of Entomology, St. Petersburg State University, St. Petersburg, Russia) kindly provided equipment and software for making digital images. The study of I.V. Shamshev was performed within the frames of the Russian State Research Project no. AAAA-A19119020690101-6 and the Presidium RAS program no.41 "Biodiversity of natural systems and biological sources of Russia”, also supported by the Russian Foundation for Basic Research (grant no. 18-04-00354A).

\section{References}

Berezhnova O.N., Shamshev I.V. 2006. New data on the genus Empis L. (Diptera: Empididae) from the forest-steppe and steppe areas of European Russia // International Journal of Dipterological Research. Vol.17. P.225-229.

Cumming J.M., Wood D.M. 2009. Adult morphology and terminology // B.V. Brown, A. Borkent, J.M. Cumming, D.M. Wood, M. Zumbado (eds.). Manual of Central American Diptera. Vol.1. Ottawa: NRC Research Press. P.9-50.

Shamshev I.V. 2016. An annotated checklist of empidoid flies (Diptera: Empidoidea, except Dolichopodidae) of Russia // Proceedings of the Russian Entomological Society. Vol.87. P.1-184.

Syrovátka O. 1991. Revision of H. Loew's and T. Becker's types of Empis s. str. species (Diptera, Empididae) in the Berlin and St Petersburg Museums // Mitteilungen aus dem Zoologischen Museum in Berlin. Bd.67. S.225-278. 